\title{
Introduction: Mexico and the Pesticide Crusade
}

\section{$\boldsymbol{I}_{\mathrm{n}}$}

1962, Rachel Carson's Silent Spring galvanized the American public into an awareness of the dangers of synthetic chemical pesticides. Her book was so sweeping in its indictment of the way society was undermining the health of nature that she is often given credit for starting the modern wave of environmental awareness that began in the I960s. More specifically, Silent Spring led to a decade of intense political infighting and scientific research resulting in the virtual banning in most industrialized nations of many persistent pesticides such as DDT. As a result of the limitations on the use of persistent pesticides, the peregrine falcon, the California brown pelican, and other species began to make an encouraging comeback. The revival of many of the declining bird populations constituted a heartening sign that humankind could recognize its errors and make amends to nature.

However, the growth of the pesticide industry continued, doubling and redoubling output since Silent Spring. Seeing their markets for the persistent pesticides drying up in the more prosperous nations, chemical companies shifted their sales to the Third World, selling there what they could no longer sell in the United States and Europe. There was some justification for this, particularly in the dependence of tropical and subtropical nations on cheap pesticides for the control of malaria and other insect-borne diseases. But the social and ecological conditions of the countries of the South tended to magnify rapidly the ill effects of dangerous pesticides. Since the most lucrative market for pesticides in the Third World was for pesticides to be applied to crops exported to richer nations, consumers in the United States and Europe began to fear that what they had prohibited at home was returning to them on the fruits and vegetables they imported from abroad. David Weir and Mark Shapiro's Circle of Poison (I98I) documented the basis for such fears and aroused the public to a new level of awareness. 
More important, the banning of some pesticides did not mean that those still allowed for use were safe or benign. Unfortunately, in many instances, pesticides that presented serious long-term environmental dangers and the possibility of cancer and other longlatency diseases were traded in for pesticides that broke down fairly rapidly in the environment under most conditions but that were far more dangerous to people, plants, and wildlife that came into immediate contact with them. This was especially tragic in the tropics, where pest problems can be particularly threatening, and where exceptionally large numbers of rural residents and farm workers came into direct contact with the chemicals due to the almost total lack of safety precautions or effective regulation. David Bull, in his littleknown but excellent book $A$ Growing Problem: Pesticides and the Third World Poor (1982), documented the tragedy, including the irresponsible behavior of chemical companies and governments. More specialized literature has subsequently pointed out the virtual total lack of meaningful regulation of the international pesticide trade and the dire consequences for people and environment of nations with little effective regulatory capacity of their own (Bull I982; Boardman I986; Wiles I983).

Recently, dramatic events have forced an even more intense awareness of the dangers of pesticides. On December 3, I984, a poisonous cloud of gas began to penetrate the houses of tens of thousands of mostly very poor people in the outskirts of Bhopal, India. Isocyanate gas used by Union Carbide Corporation in its local plant to manufacture the widely used pesticide carbaryl, or Sevin, left thousands dead (according to the Indian government, 2,500 dead; according to more carefully done surveys, about 8,000 ) and 300,000 sick and injured. Meanwhile, Robert Metcalf, the inventor of carbaryl, has been among the many pest management specialists to call for a radical turn away from reliance on chemicals to protect our crops (Kurzman 1987; Ottawa Declaration I986).

In California, a new state law that requires monitoring of water wells to detect pollutants led to the revelation that about a fifth of the wells in the state's Central Valley were contaminated with DBCP. DBCP had been used heavily throughout the world to kill nematodes, a kind of worm in the soil. In I977, men working in the Occidental chemical plant that manufactured the chemical found that they were sterile, and further investigation showed that DBCP was the cause. DBCP has been shown to be carcinogenic at very low levels of exposure as well as mutagenic. The state of California, and after a two-year delay the U.S. Environmental Protection Agency, banned the use of the chemical, but it is very stable in soils and will 
continue to travel through the ground to contaminate water sources for years, if not decades. Researchers also revealed that Dow and Shell had known of the capacity of the chemical to cause reproductive problems for nineteen years before the workers found they were sterile. The scientist who had conducted the original tests was careful to make the fine distinction that his research did not show that DBCP caused sterility, merely that it caused the testicles of mice fed the substance to atrophy. The use in the late I970s and early I980s of DBCP in banana plantations in Costa Rica apparently caused sterilization in banana workers (Gips 1987: 147-I56; Thrupp 1988; Weir 1989).

In October I986, the Sandoz Company warehouse in Basel burned, sending 66,000 pounds of pesticides into the Rhine River while bringing attention to the fact that the nearby Ciba-Geigy plant, for reasons that were unclear, was releasing large quantities of highly toxic substances into the Rhine at the same time. At least half a million fish died and towns were forced to bring water in by rail or truck until the toxic chemicals partially cleared from the river. One important consequence of the incidents in Switzerland was that the growing myth that pesticides were only a problem when handled by ill-trained people in the Third World, an explanation frequently used to explain Bhopal, was definitively put to rest (Weir 1987; Postel, in Brown I988).

We now have a very impressive literature and body of scientific data that call into serious question our global dependence on pesticides. Every year chemical companies manufacture about five billion pounds of substances chosen for their ability to kill some form of life and intended to be cast rather freely into the air, soil, and water of our planet. For all our concern with toxic waste dumps and irresponsible disposal of hazardous materials, corporations, governments, and international agencies encourage the deliberate dispersal of this fantastic quantity of biocides into the environment. Since Silent Spring, dozens of popular and technical books and thousands of articles have detailed convincing ways to grow crops and control disease with sharply reduced use of pesticides. Rachel Carson herself concluded from her survey of nonchemical means of pest control that while pesticide use was sometimes justified, "We allow the chemical death rain to fall as though there were no alternative, whereas in fact there are many, and our ingenuity could soon discover many more if given opportunity" (1962: I2). The range of nonchemical alternatives available, in spite of the near monopoly on pest control research exercised by the chemical industry, is far greater than it was a quarter of a century ago when Carson came to that con- 
clusion. (Recent summaries are National Academy of Sciences I989; Dover I985; Gips 1987; Hansen I986; classic works include Flint and van den Bosch I98I.) But the pesticide industry continues to grow more rapidly than the rest of the global economy, and international agencies operate on the assumption that it will continue to grow (Boardman 1986; UNFAO 1985).

When the growth of a technology seems immune to the consequences of disastrous experience and the invention of inexpensive and effective alternatives, we have to begin to ask why. The eminent pest management specialist, the late Robert van den Bosch, concluded that the explanation was a cynical conspiracy on the part of chemical companies, able to corrupt or intimidate government officials and scientists. Others have elaborated at length on modified versions of this theory (van den Bosch 1978). Economists have shown that much of the growth of the industry, especially in the Third World, is due to large government subsidies of pesticide use, in nine Third World nations surveyed amounting to an average of 44 percent of the retail price (Repetto I985). Clearly, there is an enormous institutional commitment to pesticide use that has a momentum of its own.

I do not reject van den Bosch's conspiracy theory-in its broad outlines I think it can be taken for granted. Any industry with a profitable product to sell will do all it can to protect and expand the market and will not hesitate to attempt to dominate scientific research and governmental actions related to the product. But to dwell on this alone is to leave very important questions unanswered. There are many ways to skin a cat, and many potential technologies that can earn a profit. Many of the alternatives to pesticides create opportunities for making profits. Why do particular technologies seem to prevail over others? I believe that for very large conspiracies to work over large geographical areas and for decades at a time, the conspiracy must be transformed into something else-a belief system, an ideology, a world view, a concept of proper professional behavior, even a crusade. Too many people are uncomfortable with playing the role of conspirator. There must be a way for Lady Macbeth to wipe out or obscure her damned spot. There must be something positive and uplifting to believe in. Such is the case with the promotion of pesticides.

A group of critics of the pesticide industry went to visit the CibaGeigy plant near Basel in I985. Ciba-Geigy executives tried to put the minds of the critics to rest, and one way they did so was to show the visitors the organic gardens the executives themselves tended 
in their yards and to show that the executives' children attended the strongly environmentally minded Waldorf schools founded by Rudolf Steiner. But, one had to understand, agriculture was not yet ready to make the transition, especially in the Third World, where the population explosion and dire poverty created an unusually strong need for the production miracles that only pesticide use could bring.

The roots for such beliefs lie in the Mexican soil. There, largely North American scientists pioneered a program of agricultural modernization that was to be called the Green Revolution. But more than new seed varieties and chemical-dependent technologies came out of this self-styled missionary effort. Far more important was the refinement in Mexico of a political strategy bolstered by an ideology of technological development. The ideology had been taking form among agricultural researchers in the United States and then was adapted for use in Mexico and other poor countries. Much of the latter half of this book is concerned with an understanding of how and why this came to pass and, most of all, with its results. By understanding what has happened in Mexico, it is easier to identify the obstacles to the transition from pesticide dependence to a healthier, more diverse agriculture.

Persistence of dangerous technologies may also be based on severe social imbalances that allow hazardous technologies to prevail because the pattern of rewards and penalties associated with the technology is rooted in the distribution of power in the society. The Mexican case is an excellent illustration, and most of the first half of the book is dedicated to showing who suffers and who gains from things as they are. Because radical imbalances of power are partly maintained, and sometimes eroded, by culture and cultural differences among people in a society, I have tried to give my reader a feeling for the cultural context of pesticide use in Mexico. The farm workers who are poisoned have very different belief systems from the ones held by the growers, chemical salesmen, investors, government officials, and researchers who perpetuate the abusive use of pesticides. These differences are at times obstacles to positive change, and they may also serve as powerful tools of change.

In particular, I came to believe that the amazing capacity of many of Mexico's poorest people for sustained effort in a single direction and for solidarity among themselves under trying circumstances could together be a significant force toward a healthier society and a more sustainable agriculture. But those people will need allies. I was also impressed that among Mexico's professional classes there is a 
substantial number of insightful and dedicated people who want to see change and who are prepared to seek out alliances to help create it.

A more important point I want to make to readers of this book in the United States is that a realistic picture of people and their dilemmas in countries like Mexico is essential to the project of humanizing the policies of our own institutions as they affect other countries. For that reason, too, I have put into my narrative a good deal of material that is about the character of the people themselves, diverse as the people of Mexico are. It would be difficult and perhaps dangerous to think about how they might resolve the political questions and technological choices before them without having some feel for what the people themselves are like.

A great deal of the pioneering work on seed varieties, chemical use, and machine use that occurred in Mexico constitutes a kind of model that has been used in dozens of other nations. The model partly came from the United States, but as we shall see, it was reshaped in Mexico and returned to the United States as one of the key influences on the modernization of agricultural technology. For economy of time and space, I have not drawn out all the implications of this story for the United States. But there are many excellent studies of the crisis of American agriculture that highlight such crucial problems as high capital costs; environmental deterioration of farmland through erosion, salinization, compaction, and chemical overload; pesticide and chemical fertilizer pollution of lakes, streams, and groundwater; unhealthy working conditions for farm workers, farmers, and farm families; dependence on a severely narrowed and destabilizing genetic base in major crops; dependence on nonrenewable mineral and energy resources; the destruction of rural communities; and the increasingly concentrated control of the nation's food supply (see, for example, Strange I 988 ; Berry I 978 ; Barney I980; Jackson et al. I984; Center for Rural Affairs I984; Moses I988; Wasserstrom and Wiles I985; USDA 1980; Sheridan I98I).

In many ways, the story of Mexican agricultural development reveals the roots of problems in the United States. In addition, by seeing the way institutions and groups have worked in Mexico, we can get a fresh perspective on the politics of our own farm economy and rural communities.

The cultures of Mexico are ancient, and so is agriculture. Mexico is one of the great world centers of the domestication of human food crops, most notably maize, or corn. For ten thousand years, apparently, Mexicans have been working on the design of agricultural technologies. In the rush to modernize Mexico, much was lost or ig- 
nored about what Mexicans had to teach us about agriculture. Much of what we know as modern agriculture developed out of Mexican crops and techniques, either through forming deliberate strategies to eliminate and replace Mexican ways considered backward or through using Mexican seed varieties or cultivation techniques as the resource for the design of modern methods. By digging briefly into the Mexican past, we understand more clearly what has been done in global agriculture and what could be done for the better.

The changes in Mexico associated with rising chemical dependence in agriculture are changes that must be understood by those north of the border. The exodus from the Mexican countryside and the explosive growth of the entire population, combined with a formerly dynamic but currently stagnating economy, are all intimately connected with the project of agricultural modernization. These things also mean two vital things to those who live in the United States. There will be a rapidly growing flow of Mexicans into the United States, and there will be insistent demands for radical political changes in Mexico of a kind that the government of the United States is likely to see as extremely threatening to the security of the United States. Based on past performance, the U.S. government will very possibly act precipitously and unwisely in the face of such change. In any case, the combination of political change in Mexico and a migration of more Mexicans into the United States will present transcendently important and complicated challenges to the government and people of the United States. Surprisingly enough, the story of how pesticides came to be so badly abused in Mexico is a good place to begin in coming to an understanding of the nature of these challenges.

Because it is diverse, because it is ancient, because it is filled with conflict, and because for all its problems it yet flies on the amazingly strong and durable wings of constant hope and good will so characteristic of many Mexicans, Mexico is simply and eternally fascinating. I hope that beyond all the sometimes too-earnest purpose behind the writing of this work, the reader will share with me the excitement of coming to know the great beauty of the Mexican land and people. 


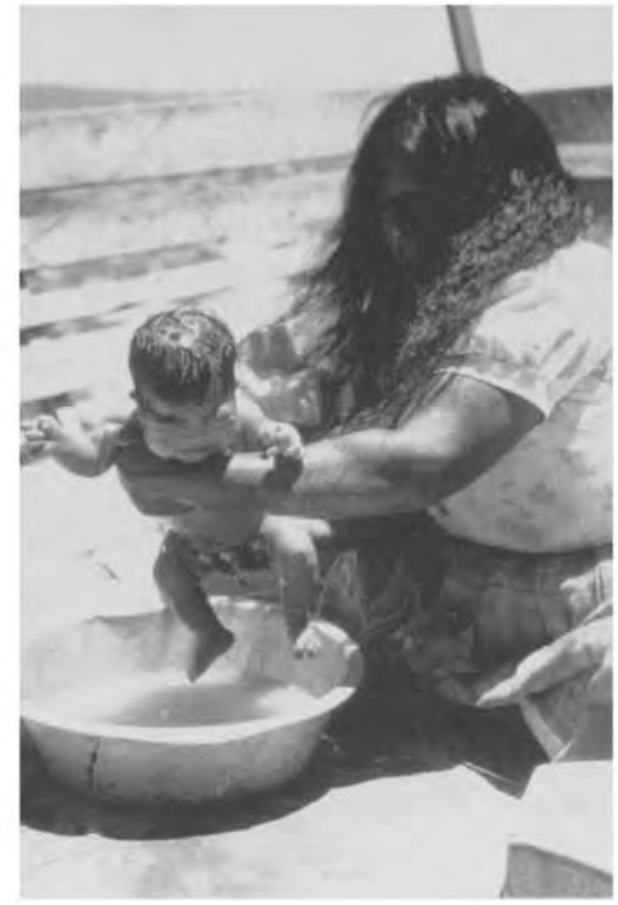

A newborn Mixtec baby in the Colonia Obrera Mixtec settlement. Photo by Michael Kearney.

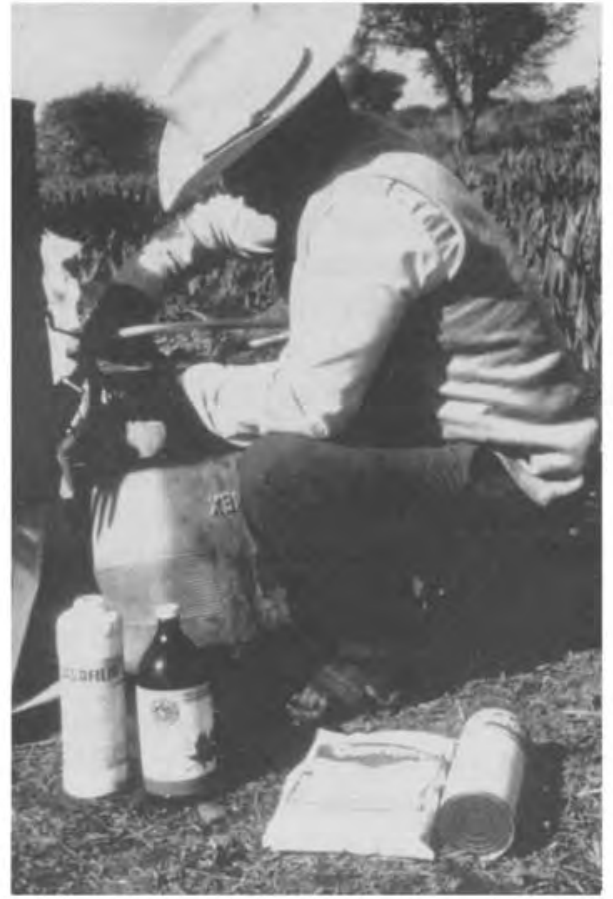

Man attempts to repair leaking spray tank that has been soaking his back with parathion, acutely toxic as a skincontact poison. His crew is spraying commercial flower fields in the Puebla Valley. 


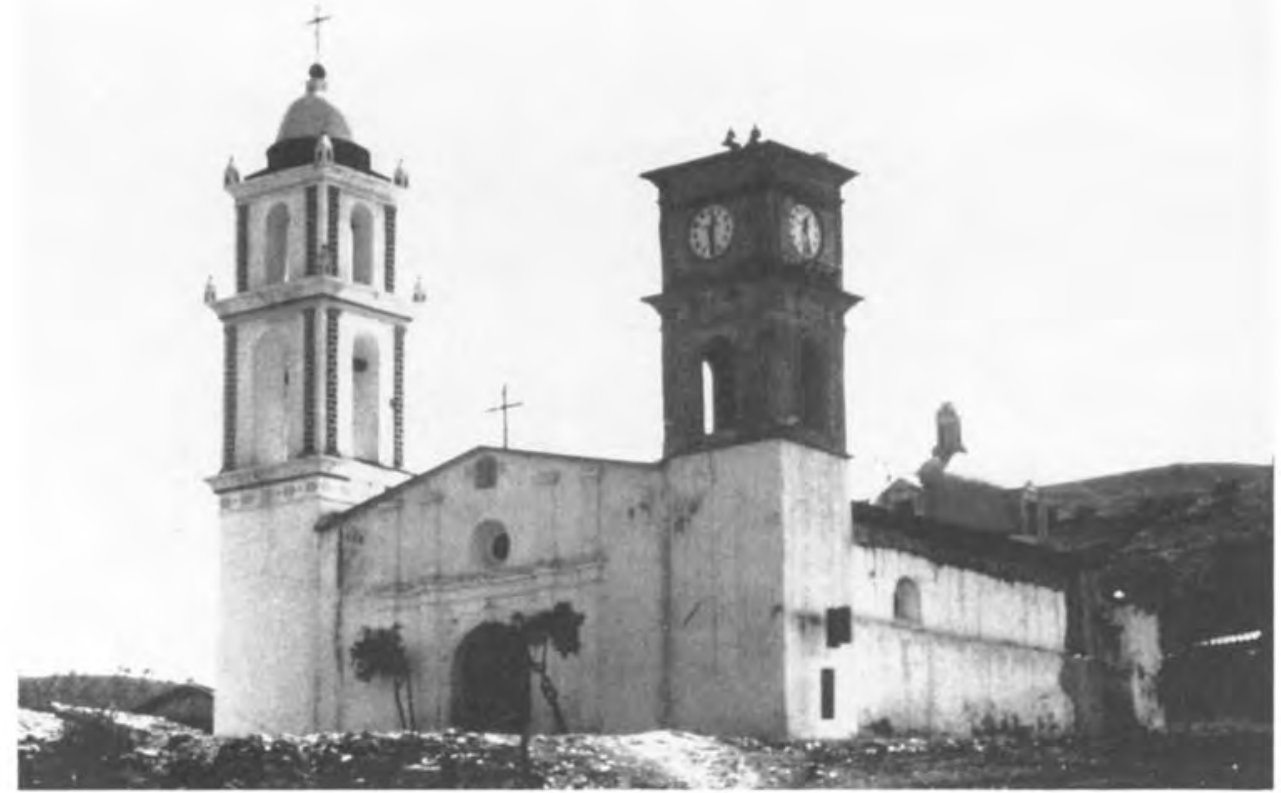

The church in San Jerónimo. The clock, newly installed, was a gift to the village from a group of San lerónimo men who wanted to commemorate a successful year as migrant workers.

Like the eroded fields of the Mixteca, the devastating deforestation of upland Chiapas causes economic losses that lead to new emigration out of the region.

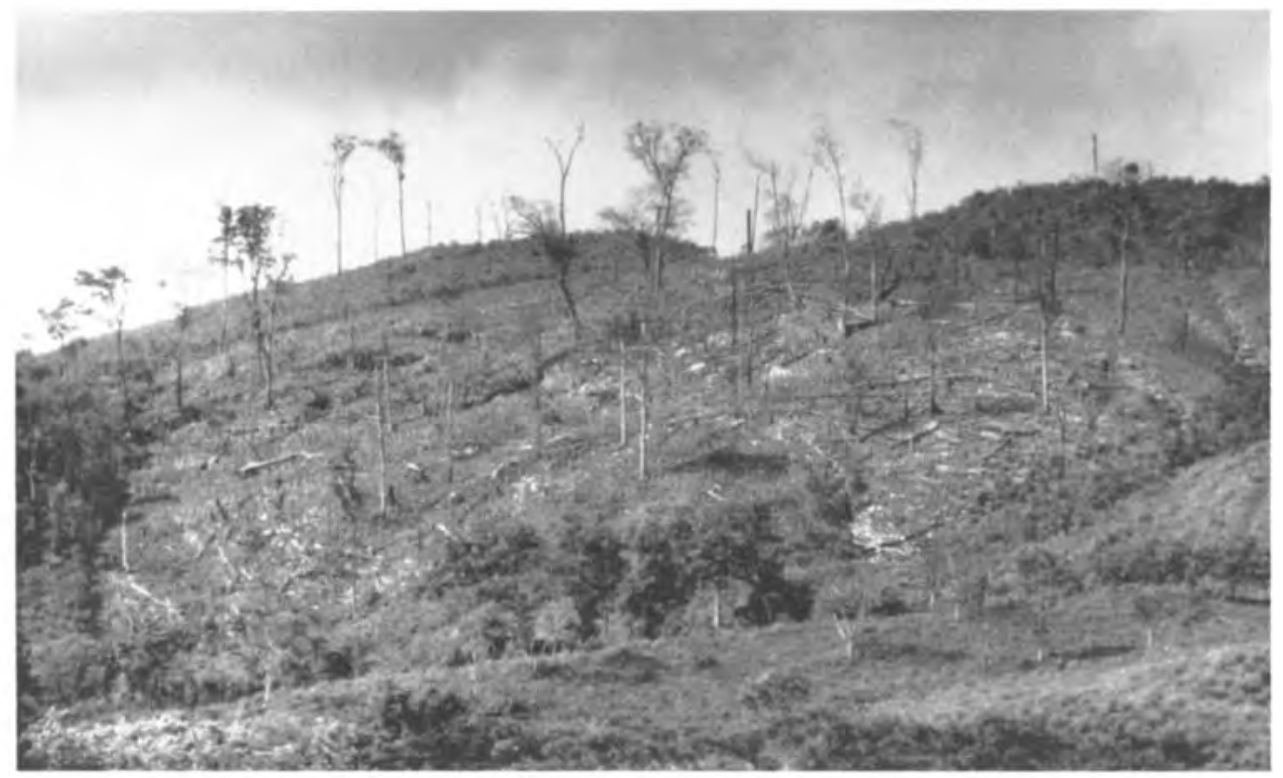




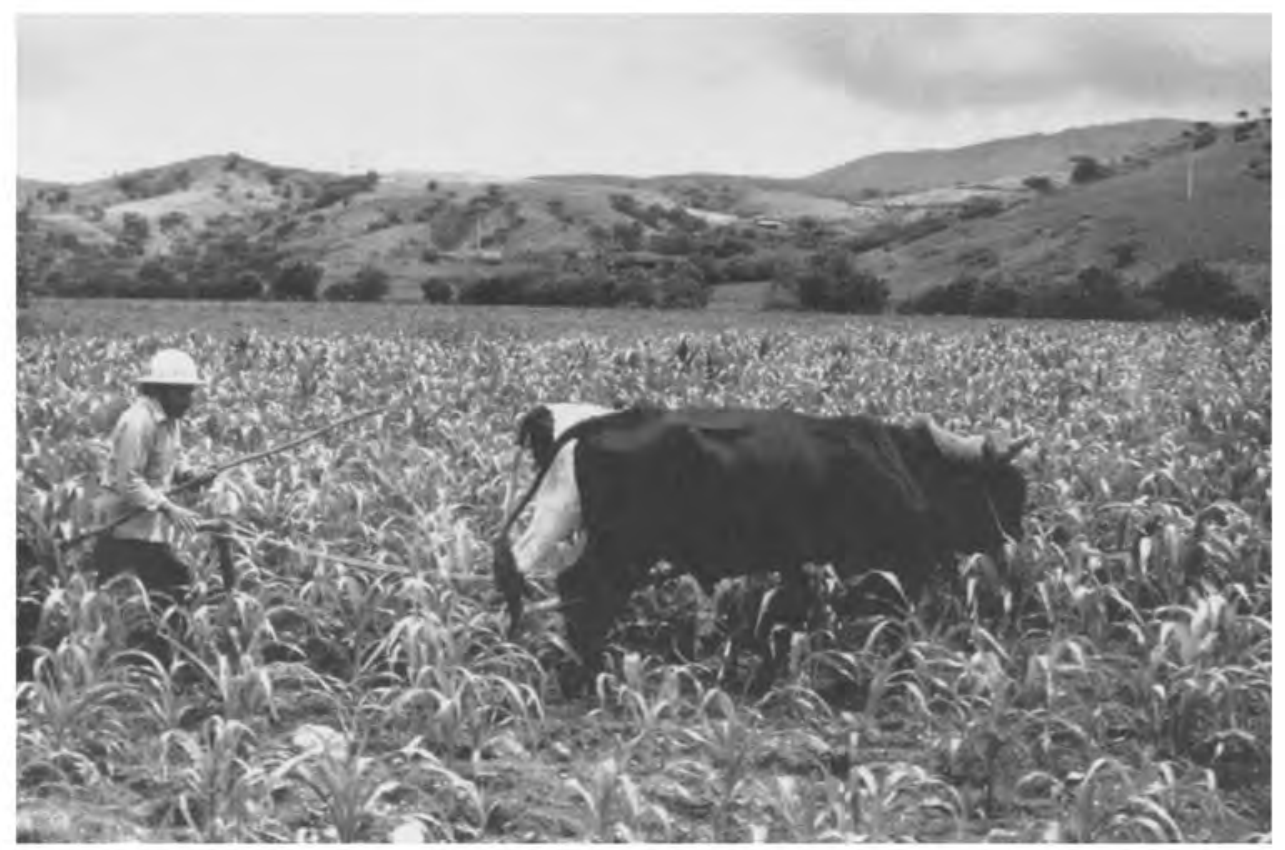

A Zapotec man who has planted his field using the traditional mix of corn, beans, and squash. He reports few pest problems.

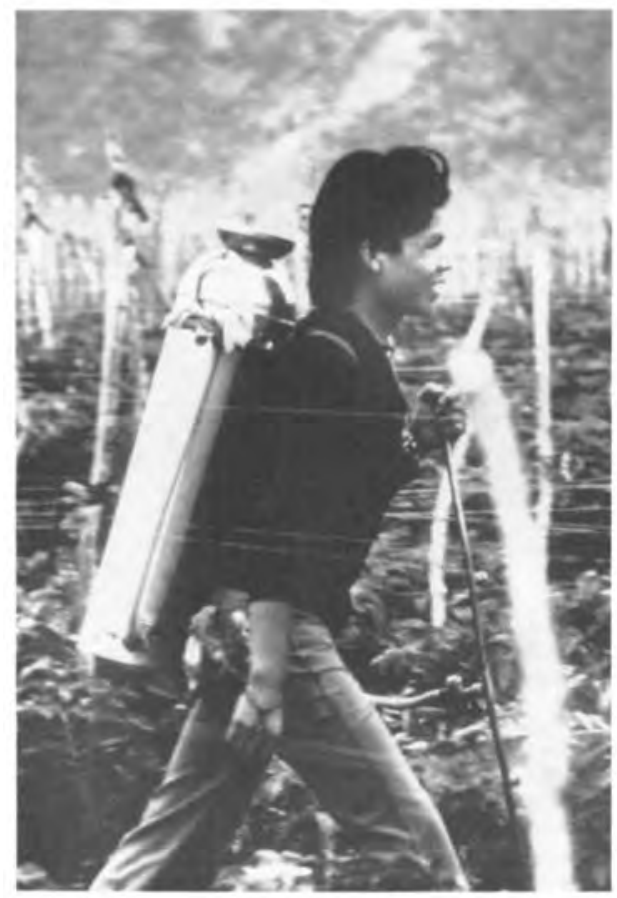

Young Mixtec man in crew spraying parathion and fungicides in San Quintín tomato fields. 
The Death of Ramón González 


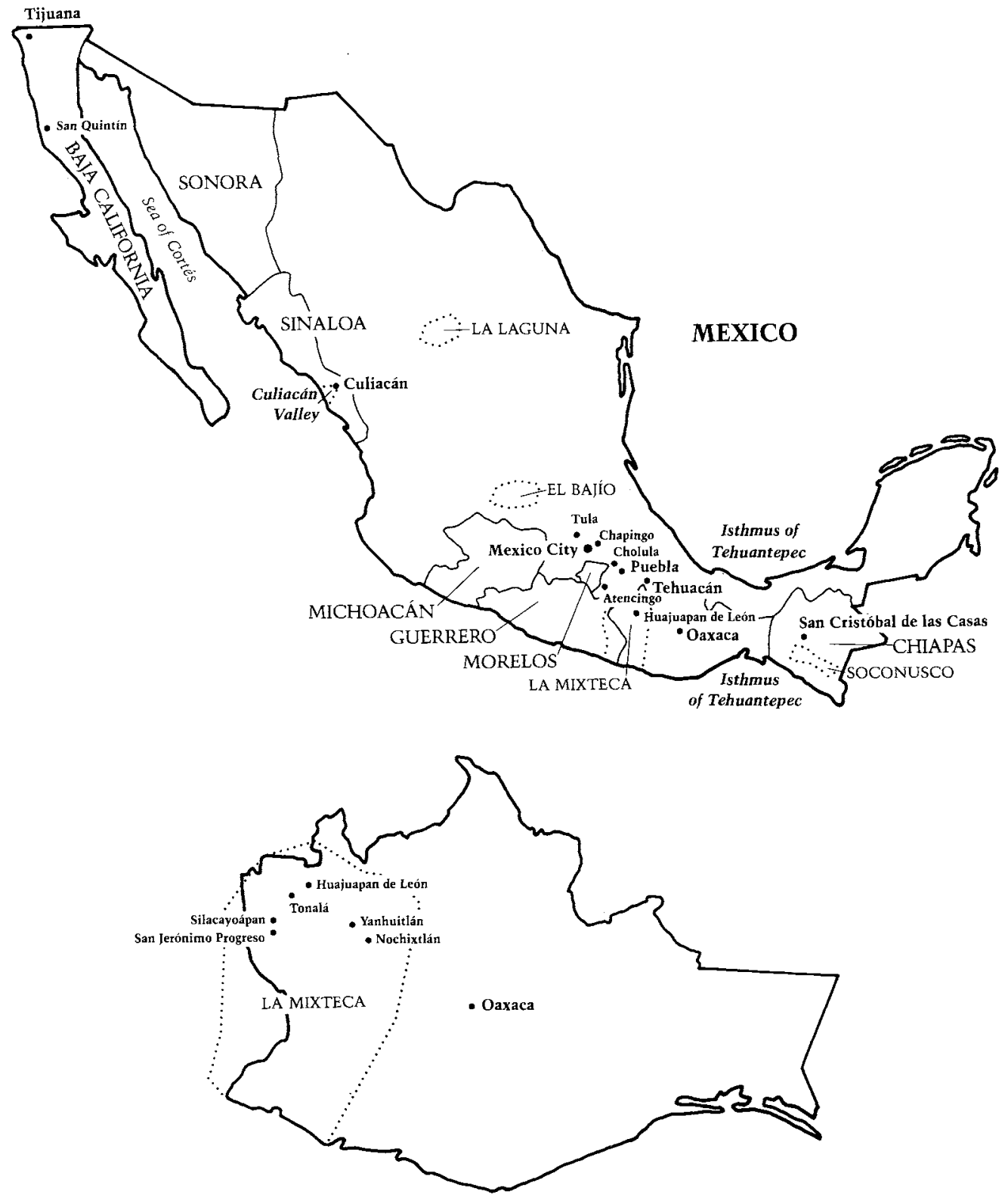

STATE OF OAXACA 